\title{
DETECTION AND IDENTIFICATION OF PHYTOPLASMA DNA IN SYMPTOMATIC MUSHROOMS OF THE GENUS RAMARIA (O. GOMPHALES)
}

\author{
by \\ MARÍA P. MARTÍN', PABLO P. DANIËLS', ESTER TORRES : \& M. TERESA TELLERÍA ' \\ ' Real Jardín Botánico, CSIC. Plaza de Murillo, 2. E-28014 Madrid \\ ' Laboratori de Sanitat Vegetal, DARP, Generalitat de Catalunya. Barcelona
}

\begin{abstract}
Resumen
Martín, M.P., P.P. Daniëls, E. ToRres \& M.T. Tellería (2003). Detección e identificación de fitoplasmas en hongos sintomáticos del género Ramaria (O. Gomphales). Anales Jard. Bot. Madrid 60(1): 11-18 (en inglés).

Mediante la reacción en cadena de la polimerasa y el uso de iniciadores específicos para la región I6S rDNA de fitoplasmas, se ha detectado por primera vez en hongos la presencia de estos organismos en basidiomas de Ramaria que presentaban un desarrollo anormal. El análisis filogenético de las secuencias por los criterios de parsimonia y de máxima verosimilitud confirman a este fitoplasma como del grupo "Stolbur".
\end{abstract}

Palabras clave: $16 \mathrm{~S}$ rDNA, iniciadores especificos, Stolbur, fungi.

\begin{abstract}
MarTí, M.P., P.P. DaniÉLS, E. TORRES \& M.T. Tellería (2003). Detection and identification of phytoplasma DNA in symptomatic mushrooms of the genus Ramaria (O. Gomphales). Anales Jard. Bot. Madrid 60(1): 11-18.

Using polymerase chain reaction assays with specific primers for amplifying phytoplasma $16 S$ rDNA, the presence of phytoplasmas in Ramaria basidiomes with abnormal development has been detected for the first time in fungi. Phytoplasmas have not been detected in asymptomatic basidiomes. Sequence analyses based on parsimony and maximum likelihood place the phytoplasma in the Stolbur group.
\end{abstract}

Key words: 16S rDNA, specific primers, Stolbur. fungi.

\section{INTRODUCTION}

Phytoplasmas are wall-less bacteria in the class Mollicutes (formerly called mycoplasmalike organisms) associated with diseases of many perennial or herbaceous crops worldwide (LHERMINIER \& al., 1999). They have a wide host range and are mostly restricted to phloem tissue. As phytoplasmas are recalcitrant to cultivation, little is known of their biology. They are specially vectored by phloem-feeding insects in which they multiply (Boudon-PADIEU \& al., 1989). During the last decade, DNA-based methods of identification have shown that phytoplasmas form a unique clade within mollicutes (SEEMÜLLER \& al., 1994). According to LHERMINIER \& al. (1999), to control the phytoplasma diseases more information is necessary on hostpathogen relationships and on the replication strategies of phytoplasmas. It has been suggested that herbaceous plants could act as a phytoplasma reservoir when the main host has disappeared.

Most species included in the genus $R a$ maria (O. Gomphales, Basidiomycotina: 
JÜLICH, 1981; HAwKSWORTH \& al., 1995) are ectomycorrhizal and they have strong fleshy and coralloid basidiomes, branching several times from the base. In general, the branch surface is smooth and basidiome apices are small and delicate, clearly distinct from the branches. Occasionally basidiomes of the ectomycorrhizal species show an abnormal growth: a) the branches become wrinkled; b) the ramification rank decreases with the branches enlarging and fusing together, and c) the apices are indistinct with the terminal branch blunted and inflated (fig. 1). However, under light microscope, no abnormal features were seen in the hyphae or spores.

Comparison of these symptoms in Ramaria with those observed in many plants at the Laboratori de Sanitat Agrària in Barcelona (Spain) suggested some kind of disease caused by a virus or phytoplasma infection. Thus, a study was undertaken to verify the presence of these pathogens in the Ramaria species with the symptoms described above. Because of their specificity and sensitivity, during the last two years we have been focusing on molecular methods to detect and identify phytoplasmas in plants based on PCR (AHRENS \& SEEMC̈LLER, 1992). According to LEE \& al. (1998) and SEemüller \& al. (1998) in phytoplasmas the $16 \mathrm{~S}$ rDNA is a very useful region to separate taxa at the species or genus level.

\section{MATERIAL AND METHODS}

DNA from less that $10 \mathrm{mg}$ of healthy and diseased Ramaria basidiomes (table 1) was obtained using E.Z.N.A. Plant MiniPrep Kit (Omega-Biotech, Doraville, USA) as described in MARTIN \& TORRES (2001).

PCR amplifications. Nested-PCR assays were performed with the primer pair P1/P7 (DENG \& HiRUKI, 1991; SMART \& al., 1996) followed by the primer pair fU5/rU3 (LORENZ \& al., 1995) amplyfing from position 369-386 to position 1251-1231. Amplifications were done using Ready-to-Go PCR Beads (Amersham-Pharmacia Biotech, Piscataway, NJ, USA) as mentioned in MARTín \& TORRES (2001). From the first PCR, $0.5 \mu \mathrm{l}$ of amplimer
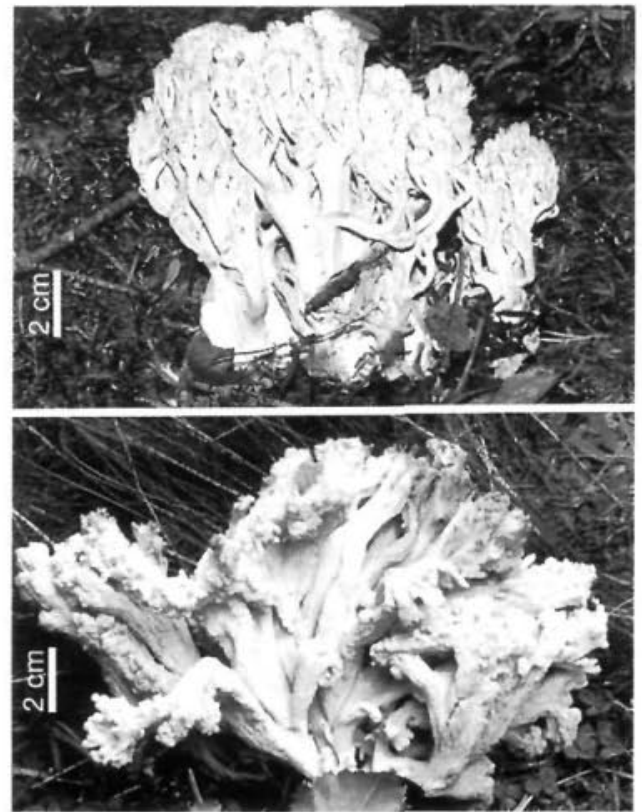

Fig. 1.-Above: Ramaria pallida (Schaeff.) Ricken (MAFungi 49659) basidiome without phytoplasma symptoms. Below: Ramaria pallida (Schaeff.) Ricken (MAFungi 49661 ) basidiome with phytoplasma symptoms.

was used as template in nested-PCR. The PCR reactions were performed by using a Techne DNA thermocycler (model Progene). The cycling parameters were 40 cycles of denaturation at $94{ }^{\circ} \mathrm{C}$ for $30 \mathrm{sec}$, annealing at $55^{\circ} \mathrm{C}$ for $1 \mathrm{~min}$, and extension at $72{ }^{\circ} \mathrm{C}$ for $1 \mathrm{~min}$ with a final extension at $72{ }^{\circ} \mathrm{C}$ for $10 \mathrm{~min}$. Before initiating the cycling parameters an initial denaturation at $94{ }^{\circ} \mathrm{C}$ for $5 \mathrm{~min}$ was done. Controls, lacking DNA, were run for each experiment to check for DNA contamination of the reagents.

DNA sequencing. Amplification products were cleaned using the E.Z.N.A. Clean kit (Omega Biotech) and both strands were sequenced separately using primers fU5 and rU3 with an ABI Prism 377 genetic Analyzer and the $\mathrm{ABI}$ Prism ${ }^{\mathrm{TM}} \mathrm{BigDye}^{\mathrm{TM}}$ terminator Cycle Sequencing Ready Reaction kit with AmpliTaq®DNA Polymerase (Perkin Elmer Applied Biosystem, Norwalk, Connecticut, USA). Sequence Navigator ${ }^{\mathrm{TM}}$ Sequence 


\section{TABLE 1}

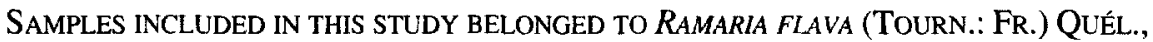
$R$. PALLIDA (SCHAEFF.) RICKEN AND R. SCHILDII R.H. PETERSEN

[indicating collection data (herbarium number, localities and dates), if basidiomes are symptomatic $(+)$ or asymptomatic $(-1)$ and the visualization of phytoplasma amplimers $(+)$ after the nested PCR with primers fU5/U3r]

\begin{tabular}{|l|c|l|c|c|c|}
\hline \multicolumn{1}{|c|}{ Taxa } & MA-Fungi & \multicolumn{1}{c|}{ Localities } & Dates & Basidiome & Nesied PCR \\
\hline R. flava & 48061 & Guadalajara, Spain & $20-\mathrm{XI}-1998$ & - & - \\
R. flava & 51163 & Valbella, Switzerland & $12-\mathrm{IX}-2000$ & + & +(FITOPL_4) \\
R. pallida & 39878 & Segovia, Spain & $25-\mathrm{X}-1997$ & + & +(FITOPL_2) \\
R. pallida & 48066 & Huesca, Spain & $2-\mathrm{X}-1999$ & - & - \\
R. pallida & 49661 & León, Spain & $13-\mathrm{IX}-1997$ & + & +(FITOPL_1) \\
R. schildii & 50726 & Lenzerheide, Switzerland & $8-\mathrm{IX}-1999$ & + & +(FITOPL_3) \\
\hline
\end{tabular}

Comparison software (Perkin Elmer) was used to identify the consensus sequence from the two strands of each ITS region.

To control for possible contamination of extractions, amplifications and sequencing reactions were replicated at the Laboratori de Sanitat Agrària (Barcelona) and at the Real Jardín Botánico (Madrid) following the same protocols as mentioned above, but independent reagents and a thermocycler Perkin Elmer 9700.

Analyses of data. The nucleotide sequence obtained (FITOPL_1) has been logged in the EMBL database and has been compared with 59 sequences retrieved from the EMBL GenBank (table 2). To search for the best alignment Sequence Navigator ${ }^{\mathrm{TM}}$ Sequence Comparison for pairwise comparisons and SEQAPP software for multiple sequences were used. Where ambiguities in the alignment occurred, the alignment chosen was the one generating the fewest potentially informative characters. Alignment gaps were marked "." and unresolved nucleotides or unknown sequences were indicated with "N".

Parsimony analysis was performed using the computer program PAUP 4.0b* (Phylogenetic Program Using Parsimony) of SwoFFORD (1998). Clostridium innocuum and Acholeplasma laidlawii were used as outgroup. Branch robustness was estimated by bootstrap analysis (FELSENTEIN, 1985) of
10,000 heuristic replicates using the fast stepwise-addition option. In the maximum likelihood analysis (ML) (FELSENSTEIN. 1981) optimality criterion was employed.

\section{RESULTS}

No PCR products were visualized with primers P1/P7 from any of the collections analyzed. With fU5/rU3 no amplifications were obtained from asymptomatic collections. The four symptomatic samples give amplifications of $850 \mathrm{bp}$, in agreement with the expected size, but only from FITOPL_1 was the concentration enough for sequencing. Moreover, in FITOPL_2 and FITOPL_4 an extra band about $800 \mathrm{bp}$ was visualized.

The sequence length obtained is $800 \mathrm{bp}$ and has been logged in the NCBI with the Accession Number AJ430066. The sequences of the 60 taxa were aligned to produce a matrix of 826 characters, of which 203 were parsimony-informative.

Two hundred most parsimonious trees were obtained under heuristic search with a tree length of 723 steps, $\mathrm{Cl}=0.6321, \mathrm{RI}=$ $0.8845, \mathrm{RC}=0.5591$. In the strict consensus tree (fig. 2) the sequence obtained cluster with phytoplasmas from Stolbur group with $99 \%$ bootstrap support. The topology of the ML tree agrees with the consensus tree inferred from heuristic search (fig. 3). 


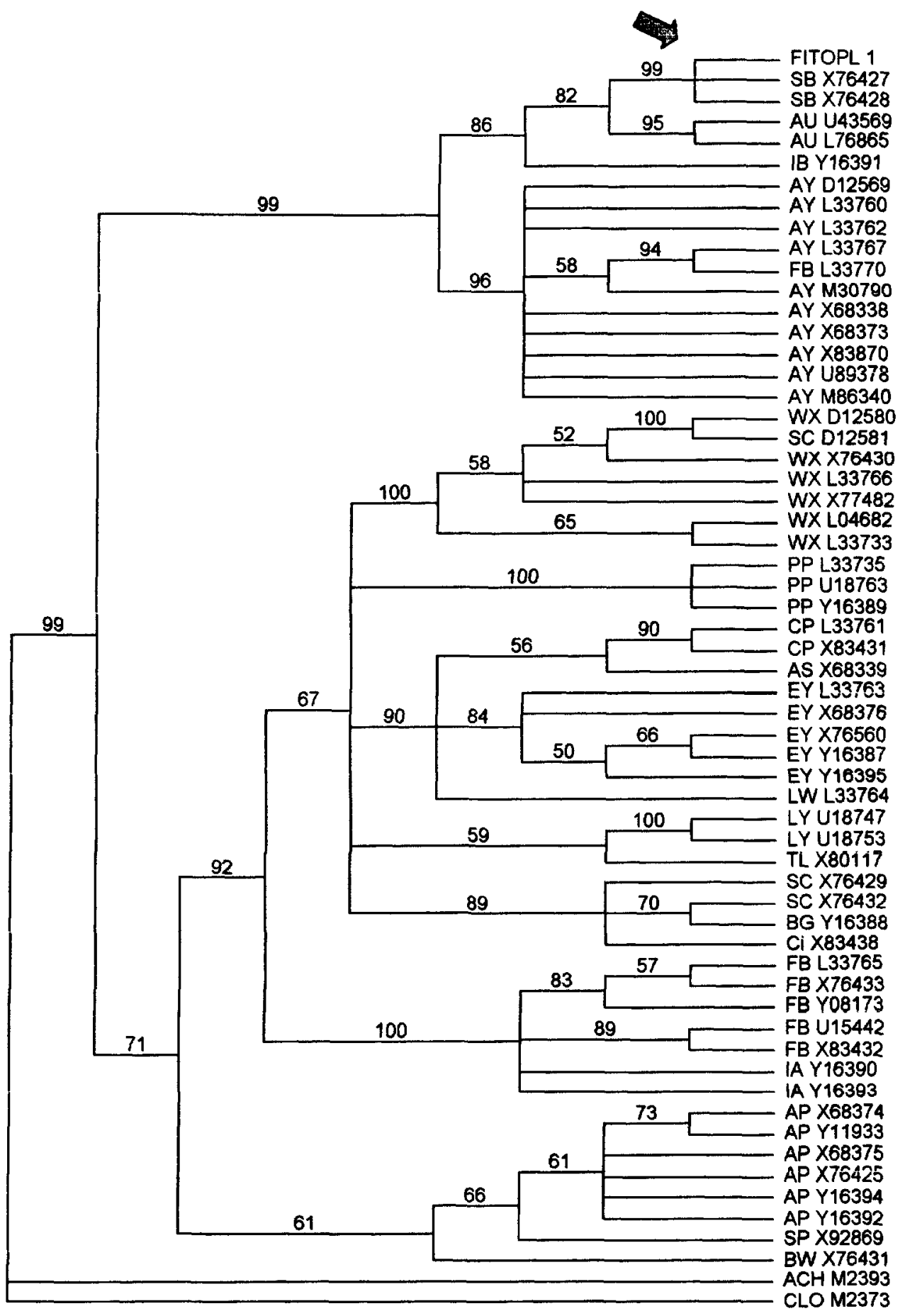

Fig. 2.-Strict consensus tree of 200 MPTs obtained from parsimony analysis under heuristic search. Bootstrap support values are shown at the nodes. Names according to tables 1 and 2 . 


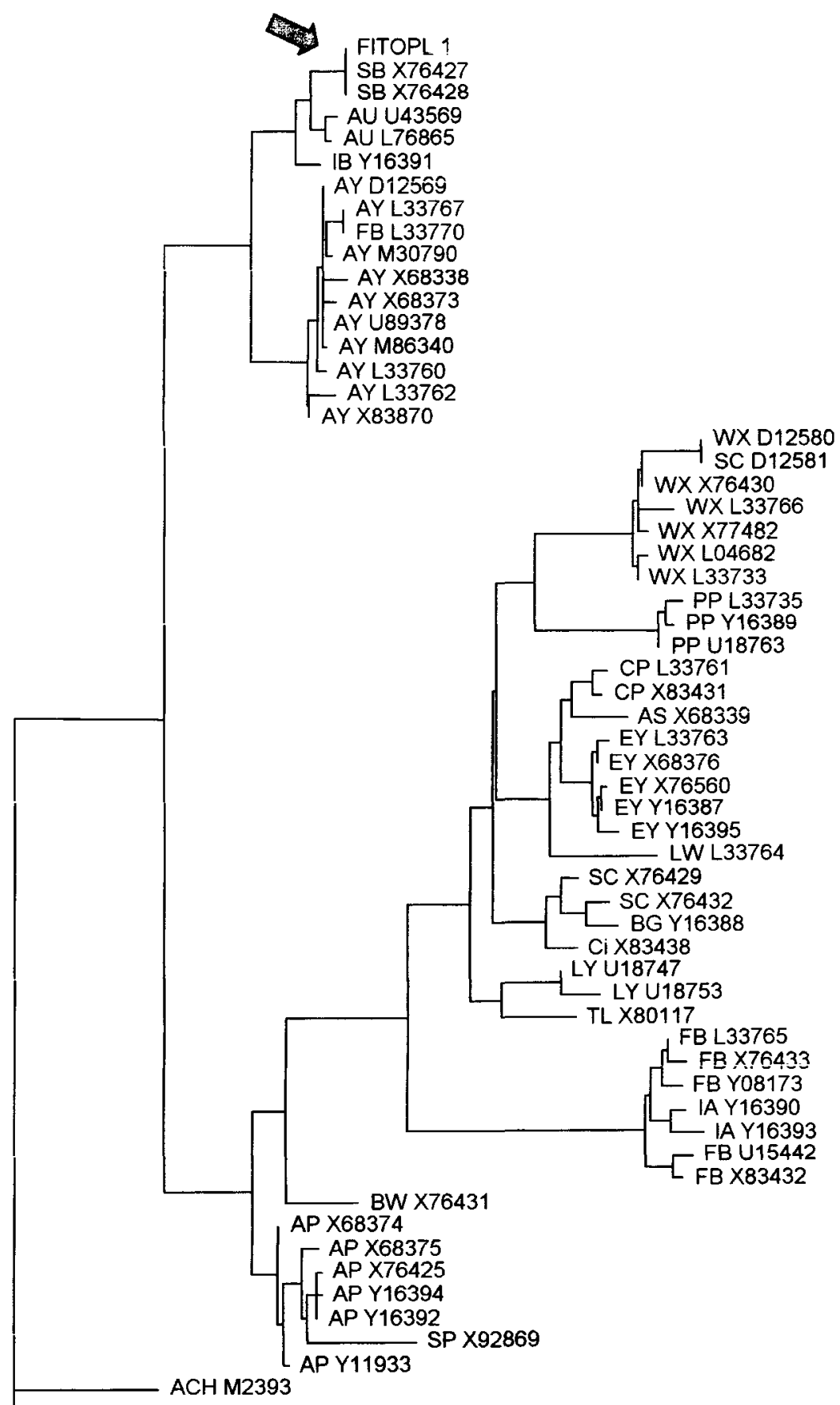

-0.005 substitutions/site

Fig. 3.-The most likely tree found in the maximum likelihood search using a manually optimized alignment. No characters excluded. Names according to tables 1 and 2. 
TABLE 2

SEQUENCES RETRIEVED FROM GENBANK INDICATING THE CLASSIFICATION PROPOSED BY SEEMÜLLER \& AL. (1998), AS WELL AS THE CODE MENTIONED PREVIOUS TO THE ACCESSION NUMBER (EMBL) INCLUDED IN FIGURES 2 AND 3

\begin{tabular}{|c|c|c|c|c|c|}
\hline Identification & Code & GenBank No. & Identification & Code & Genbank No. \\
\hline Apple proliferation & AP & X68374 & Faba bean phyllody & FB & L33765 \\
\hline Apple proliferation & AP & X68375 & Faba bean phyllody & FB & L33770 \\
\hline Apple proliferation & AP & $X 76425$ & Faba bean phyllody & FB & $\mathrm{U} 15442$ \\
\hline Apple proliferation & AP & Y11933 & Faba bean phyllody & FB & $X 76433$ \\
\hline Apple proliferation & AP & Y16392 & Faba bean phyllody & FB & X83432 \\
\hline Apple proliferation & AP & Y16394 & Faba bean phyllody & FB & Y08173 \\
\hline Ash yellows & AS & X68339 & Italian alfalfa witches' broom & IA & Y16390 \\
\hline Aster yellows & AY & D12569 & Italian alfalfa witches' broom & IA & Y16393 \\
\hline Aster yellows & AY & L33760 & Italian bindweed stolbur & IB & Y16391 \\
\hline Aster yellows & AY & $X 83870$ & Loofah witches broom & LW & L33764 \\
\hline Aster yellows & AY & L33762 & Phytoplasma australiense & $\mathrm{AU}$ & L76865 \\
\hline Aster yellows & AY & L33767 & Phytoplasma australiense & $A U$ & U43569 \\
\hline Aster yellows & AY & M30790 & Pigeon pea witches' broom & PP & L33735 \\
\hline Aster yellows & AY & M86340 & Pigeon pea witches' broom & PP & U18763 \\
\hline Aster yellows & AY & U89378 & Pigeon pea witches' broom & PP & Y16389 \\
\hline Aster yellows & AY & X68373 & Spartium witches' broom & SP & X92869 \\
\hline Aster yellows & AY & X68338 & Stolbur & SB & $\times 76427$ \\
\hline Bermuda grass white leaf & BG & Y 16388 & Stolbur & SB & $\times 76428$ \\
\hline Buckthorn witches' broom & BW & $\times 76431$ & Sugarcane white leaf & $\mathrm{SC}$ & D12581 \\
\hline Cirsium phyllody & $\mathrm{Ci}$ & $\mathrm{X} 83438$ & Sugarcane white leaf & $\mathrm{SC}$ & X76429 \\
\hline Clover proliferation & $\mathrm{CP}$ & L.33761 & Sugarcane white leaf & $S C$ & $\times 76432$ \\
\hline Clover proliferation & $\mathrm{CP}$ & $X 83431$ & Tanzanian lethal decline of & TL & $X 80117$ \\
\hline Cocconut lethal yellowing & LY & U18753 & cocconut & & \\
\hline Cocconut lethal yellowing & LY & U18747 & Western X-disease & WX & D12580 \\
\hline Elm yellows & EY & L33763 & Western X-disease & WX & L04682 \\
\hline Elm yellows & EY & $\mathrm{X} 68376$ & Western X-disease & WX & L33733 \\
\hline Elm yellows & EY & $X 76560$ & Western X-disease & WX & L33766 \\
\hline Elm yellows & EY & Y16387 & Western X-disease & WX & X76430 \\
\hline Elm yellows & EY & Y16395 & Western X-disease & WX & X77482 \\
\hline
\end{tabular}

\section{DISCUSSION}

The highly sensitive nested-PCR combined with the use of specific primers has made possible the detection of phytoplasmas in symptomatic basidiomes of Ramaria. The absence of visible products from samples amplified by direct PCR with P1/P7 is probably due to the low concentration of these prokaryotes as described in plant hosts (BERTACCINI \& al., 1996).

Plants infected by phytoplasmas exhibit an array of symptoms that suggest profound disturbance in the normal balance of plant hormones or growth regulators. The stolbur phy- toplasma is an ubiquitous agent that multiplies in a broad range of cultivated and wild plant species (GARNIER, 2000). The symptoms change according to the host, some affected plants shown variegate branches, as observed in olive-trees (TORRES \& MARTIN, unpublished). These symptoms are the same as detected in Ramaria spp. and fit with the molecular analysis, that includes phytoplasmas found in this fungus as belonging to the stolbur group. These phytoplasmas are very frequent in wild plants found in infected grapevines. BATLLE \& al. (2000) identified stolbur phytoplasmas in Convolvulus arvensis, Lavandula officinalis, Polygonum con- 
volvulus, Solanum nigrum and Thymus officinalis. According to our molecular analysis, stolbur group phytoplasmas are the sister group of the Aster yellows phytoplasma clade.

On the other hand, several taxa of clavarioid fungi have been described as new species, in which the basidiomes show the same features as the symptomatic and positive phytoplama-infected basidiomes included in this study: Ramaria obtusissima (Peck) Corner (PECK, 1913; ChrISTAN, 2000), Ramaria claviramulata Marr \& Stuntz (MARR \& STUNTZ, 1973; HUMPERT \& al., 2001), Ramaria rielii Boud. (BOUDIER, 1897; DANIËLS \& Tellerfa, 2000), Clavaria strasseri subsp. cornucervi Killermann (KILLERMANN, 1956), Clavaria anomala Fr. (FRIES, 1821; SCHAEFFER, 1774), Clavulina cristata var. subrugosa Corner and Clavulina rugosa (Fr.) Schroet. (CORNER, 1950). An accurate molecular analysis should be done in these taxa to know if the basidiomes are infected by phytoplasma. However, only by inoculating phytoplasmas in young basidiomes is it possible to state that the abnormal morphology of the basidiome is clearly related to the presence of the phytoplasma.

\section{ACKNOWLEDGEMENTS}

To the Asociación Vallisoletana de Micología for sending the sample MA-Fungi 49661. To Dr. Fernando Esteve for the collection and figure of Ramaria pallida (MA-Fungi 49659). This grant was supported by a postdoctoral grant to the Comunidad de Madrid to MPM and by DGES under the research project Flora Micológica Ibérica PB98-0538-C04-01.

\section{REFERENCES}

AHRENS, U. \& E. SEEMÜLLER (1992). Detection of DNA of plant pathogenic Mycoplasmalike organisms by a polymerase chain reaction that amplifies a sequence of the 16S rRNA gene. Phytopathology 82(8): 828 832.

Batlle, A., M.A. Martínez \& A. LAviña (2000). OCcurrence, distribution and epidemiology of grapevine yellows in Spain. Eur. J. Plant Pathol. 106 (9): 811 816.
Bertaccini, A., L. MittemPerCher \& M. Vibio (1996). Identification of phytoplasmas associated with a decline of European hackberry (Celtis australis). Ann. Appl. Biol. 128: 245-253.

BoudiER, E. (1897). Nouvelles espèces ou variétés de champignons de France. Bull. Soc. Mycol. France. 13: 11-18.

Boudon-Padieu, E.. J. Larrue \& A. Caudwell (1989). ELISA and Dot Blot detection of Flavescence dorée in individual leafhopper vectors during latency and inoculative state. Current Microbiology 19: 357-364.

Christan, J. (2000). Vergleiche und Klärung zu Verwechlungen von Ramaria flava-R. obtusissimaR. schildii. Österr. Z. Pilzk. 9: 115-123.

CORNER, E.J.H. (1950). Monograph of Ramaria and allied genera. Ann. Bot. Mem. 1: 1-740.

DANIËLS, P.P. \& M.T. Tellerf́a (2000). Notes on Gomphales: Ramaria rielii. Mycotaxon 74(2): 423-427.

DENG, S.J. \& C. HIRUKI (1991). Amplification of $16 \mathrm{~S}$ rRNA genes from culturable and nonculturable mollicutes. J. Microbiol. Methods 14: 53-61.

FELSENSTEIN, J. (1981). Evolutionary trees from DNA sequences: a maximum likelihood approach. $\mathrm{J}$. $\mathrm{Mol}$. Evol. 17: 368-376.

Felsenstein, J. (1985). Confidence limits on phylogenies: an approach using the bootstrap. Evolution 39: 783-791.

FRIES, E.M. (1821). Systema mycologicum. Lund, Gryphiswaldiae. 1: 1-520.

GARNIER, M. (2000). Le phytoplasme du stolbur: Un agent ubiquiste. C. R. Acad. Agric. Fr. 86(7): 27-33.

HawkworTh, D.L., P.M. KIRK, B.C. SuTton \& D.N. PEGLER (1995). Dictionary of the fungi. CAB International. Oxon, U.K.

Humpert, A.J., M.A. Castellano \& J.W. Spatafora (2001). Molecular phylogenetics of Ramaria and related genera: evidence from nuclear large subunit and mitochondrial small subunit rDNA sequences. $M y$ cologia 93(3): 465-477.

JÜICH, W. (1981). Higher taxa of Basidiomycetes. Bibliotheca Mycologica 85: 1-845.

KillermanN, S. (1956). Studien zur Clavaria-Gruppe I. Z. Pilzk. 12: 4-9.

LEE, I.-M., D.E. GuNDERSEN-RINDAL, R.E. DAVIS \& I.M. BARTOSZYK (1998). Revised classification scheme of pytoplasmas based on RFLP analyses of 16S rRNA and ribosomal protein gene sequences. Int. J. Syst. Bacteriol. 48: 1153-1169.

Lherminier, J., R.G. Bonfiglioli, X. Daire, R.H. SymONS \& E. Boudon-PAdieu (1999). Oligodeoxynucleotides as probes for in situ hybridization with transmission electron microscopy to specifically localiza phytoplasma in plant cells. Mol. Cell. Probes. 13: 41-47.

LORENZ, K.H., B. SChNeIder, U. Ahrens \& E. SEEMÜLLER (1995). Detection of the apple proliferation and pear decline phytoplasmas by PCR amplification of ribosomal and non ribosomal DNA. Phytopatho$\log y$ 85(7): 771-776.

MARR, C.D. \& D.E. STUNTz (1973). Ramaria of Western Washington. Biblioth. Mycol. 38: 1-232. 
Martín, M.P. \& E. Torres (2001). Evaluación de métodos basados en la PCR para la detección del fitoplasma asociado a la enfermedad de la "Flavescencia dorada" en vid. Bol. San. Veg., Plagas 27: 217-224.

PECK, C.H. (1913). New species of extralimital fungi Bull. New York State Mus. Nat. Hist. 167: 38-50.

SCHAEFFER, J. (1774). Fungorum qui in Bavaria et Palatinatu circa Ratisbonam nascuntur. Zunkelianis, Ratisbonae. $4: 326$.

SeEmuller, E., B. Schneider, R. MAurer, U. Ahrens, X. Daire, H. Kison, K.H. Lorenz, G. Firrao, L. AviNENT, B.B. Sears \& E. Stackebrandt (1994). Phylogenetic classification of phytopathogenic mollicutes by sequence analysis of $16 \mathrm{~S}$ ribosomal DNA. Int. $J$. Sys. Bacteriol. 44: 440-446.
Seemüller, E., C. Marcone, U. Lauer, A. Ragozzino, M. GoesCHL (1998). Current status of molecular classification of the phytoplasmas. Plant Patholol. 80(1): 3-26.

Smart, C.D., B. Scheneider, C.L. Blomquist, L.J. GuERRA. N.A. HARRISON, U. AHRENS, K.H. LORENZ. E. SEemuller \& B.C. KIRHKPATRICK (1996). Phytoplasma-specific PCR primers based on sequences of the 16S-23S rRNA spacer region. Appl. Environ. Microbiol. 62(8): 2988-2993.

SWOFFORD, D.L. (1998). PAUP*. Phylogenetic analysis using parsimony (*and other methods). Version 4. Sunderland, Mass.: Sinauer Associates. 128 pp.

Editado por Carlos Lado Aceptado para publicación: 21-XI-2002 